Pamiętnik Literacki 2014, 2, s. 5-20
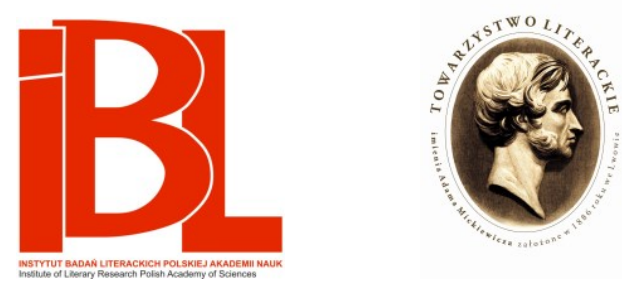

\title{
Przestrzeń historii, przestrzeń tekstu - paralele Lelewela i Mickiewicza
}

Danuta Zawadzka 


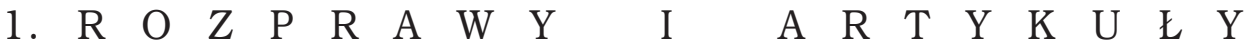

Pamiętnik Literacki CV, 2014, z. 2, PL ISSN 0031-0514

DANUTA ZAWADZKA Uniwersytet w Białymstoku

\section{PRZESTRZEŃ HISTORII, PRZESTRZEŃ TEKSTU - PARALELE LELEWELA I MICKIEWICZA*}

Punktem wyjścia moich rozważań jest dzieło Joachima Lelewela Historyczna paralela Hiszpanii z Polska $w$ XVI, XVII, XVIII wieku i pytanie o jego wpływ na ówczesną literaturę. Podobne założenie może wydać się arbitralne, ma jednak za sobą pewną tradycję badawcza - przed 50 laty Wacław Kubacki w paralelach upatrywał istotę historyzmu romantycznego i wywodził je właśnie od Lelewela:

Aktualność „historycznych” tragedii i romansów rycerskich, jakie pisali klasycy, była powierzchowna, polegała na przypadkowych podobieństwach sytuacji; jej mechanizmem literackim jest aluzja. Aktualność historycznych dzieł romantyków wynika $z$ analogii historycznych. Mechanizmem aktualizacji romantyków jest paralela history czna. Dzielny to środek agitacyjny, wypróbowany w publicystyce historycznej i politycznej. Przykładem: Historyczna paralela Hiszpanii z Polska w wieku XVI, XVII i XVIII Lelewela oraz szkic Petersburg i Konstantynopol Mochnackiego ${ }^{1}$.

Kubacki wskazuje na Lelewela i Mochnackiego jako ojców myślenia opartego na analogii, ale szkic tego ostatniego Petersburg i Konstantynopol (1832) jest dużo późniejszy w stosunku do napisanej w 1820 r. paraleli hiszpańsko-polskiej, opublikowanej 11 lat później w powstańczej Warszawie. Tym większe ma to znaczenie, że w moich rozważaniach literaturę będzie reprezentował Adam Mickiewicz, którego związki biograficzne $z$ Lelewelem pozwalają przyjmować możliwość poznania Historycznej paraleli jeszcze przed jej ogłoszeniem, przypuszczalnie w latach 1822-1824. Wówczas to Lelewel powrócił do Wilna na tzw. drugą profesurę i podjął wykłady z historii starożytnej oraz powszechnej (z elementami „historyki”, tj. metodologii historycznej), Mickiewicz zaś, zniechęcony do Kowna, często odwiedzał swoich wileńskich kolegów, a także samego profesora historii. Wtedy też bliżej poznali się i zaprzyjaźnili, czego dowodem świadczący o fascynacji historią i osobą profesora wiersz Mickiewicza Do Joachima Lelewela (1822), jak też późniejsze wydarzenia towarzyszące procesowi filomatów, zwłaszcza fakt, że poeta został zwolniony $\mathrm{Z}$ więzienia za poręką Lelewela.

Ścisłe związki biograficzne obu twórców w połączeniu z uwagą Kubackiego wskazującą Lelewelowski rodowód romantycznego historyzmu literackiego skła-

* $\quad$ Ustalenia tu zawarte wykorzystuję w mojej książce Lelewel i Mickiewicz. Paralela (Białystok 2013), która ukazała się po złożeniu artykułu do druku.

1 W. Ku b a c ki, Twórczość Feliksa Bernatowicza. Wrocław 1964, s. 48. 
niają do przypomnienia i nieco obszerniejszego prześledzenia niektórych aspektów narracji historycznych wileńskiego profesora. Wydaje się również, że w przypadku późniejszych, emigracyjnych dzieł Lelewela można mówić z kolei o inspirowaniu się Mickiewiczem, zwłaszcza że ich autor od początku przejawiał zainteresowanie utworami $z$ pogranicza literatury i dziejopisarstwa, recenzując Pielgrzyma $w$ Dobromilu Izabeli Czartoryskiej oraz Śpiewy historyczne Juliana Ursyna Niemcewicza. Jeśli zaś pojęcie „wpływu” Lelewela na Mickiewicza (oraz w przeciwną stronę) wydawałoby się nazbyt zobowiązujące, warto przynajmniej sprawdzić, na ile bliskie było myślenie i pisanie o historii w przypadku ludzi, którzy w swoim czasie doskonale się rozumieli ${ }^{2}$.

Historyczna paralela Hiszpanii z Polską należy do najbardziej znanych tekstów Lelewela, najbardziej cenionych i odpornych na dezaktualizację, przyciaga bowiem zainteresowanie również dzisiejszych badaczy. Mimo zapomnienia Lelewela przez historyków i polonistów ukazała się w r. 2006 jej reedycja, ze wstępem Jana Kieniewicza ${ }^{3}$, podczas gdy jedyne powojenne wydanie Dziet Lelewela, zainicjowane w 100-lecie śmierci dziejopisarza, w tajemniczy sposób utknęło, choć w 2011 r. minęła już kolejna, 150 jej rocznica. Edycja Kieniewicza różni się od tej zbiorowej, zawiera odnaleziony przez Teresę Wysokińską dalszy fragment Paraleli, zatytułowany przez historyka w manuskrypcie: Kontynuacja. Polacy i Hiszpanie próbuja się podźwignać ${ }^{4}$. Zatem dzieło, które Lelewel stworzył w r. 1820, w początkowym etapie kariery naukowej i pisarskiej, następnie bez poprawek ogłosił w r. 1831, kontynuował również potem - jak przypuszcza Kieniewicz, w r. 1836 lub 1837 - na emigracji, w Brukseli. Musiało więc być ono istotne dla samego autora, niezależnie od zmieniających się okoliczności biograficznych i politycznych.

Od dawna też cieszy się Historyczna paralela uznaniem komentatorów jako pionierska na polskim i europejskim gruncie, oryginalna próba komparatystyki historycznej. Pisali o niej niemal wszyscy badacze Lelewela, wiążąc wypracowana przezeń metodę porównawczą $z$ wykładem historii powszechnej i jego wymogami ${ }^{5}$. Dokumentowane już tylko w tytułach pism przykłady komparatystyki Lelewela

2 W tej sprawie nie ma jasności. Z nielicznych prac ostatniego półwiecza wynika, że historycy literatury raczej nie dostrzegają istotnych związków między Mickiewiczem a Lelewelem (zob. K. G ó rs ki, Mickiewicz - Lelewel. Toruń 1986. - J. Ław s ki, Mickiewicz-mit-historia. Studia. Białystok 2010, s. 207, 233), historycy historiografii zaś zauważają podobieństwo ich syntez historycznych, które określają jako „dwa, choć znacznie odmienne, ujęcia tej samej idei” (M. W ierzbicka, Lelewel a Mickiewicz. Problem trwałości romantycznych koncepcji dziejów Polski. W zb.: Joachim Lelewel - człowiek i dzieło. W 200-lecie urodzin. Materiały z ogólnopolskiej sesji naukowej, Żagań, 12-14 IX 1986. Red. K. Bartkiewicz. Zielona Góra 1988, s. 242); w tym duchu pisze też o Mickiewiczu, zaliczając jego prelekcje paryskie do historiografii romantyzmu, A. W i e r z b i c k i w pracach Historiografia polska doby romantyzmu (Wrocław 1999, s. 426) oraz Spory o polska duszę. Z zagadnień charakterologii narodowej $w$ historiografii polskiej XIX $i$ XX wieku (wyd. 2, rozszerz. Warszawa 2010, s. 76-107).

3 J. Le le w e 1, Historyczna paralela Hiszpanii z Polska w XVI, XVII, XVIII wieku. Wyd. nowe. Przygot. J. Kieniewicz. Warszawa 2006. Dalej do tego dzieła odsyłam skrótem L. Liczba po skrócie wskazuje stronice.

$4 \quad$ Zob. J. Ki e ni e wi c z, Dlaczego trzeba czytać Lelewela? L 9.

5 Wcześniejsze prace omawia M. H. Serejs ki (Paralela Hiszpanii z Polska. W: Koncepcja historii powszechnej Joachima Lelewela. Warszawa 1958, s. 376-378). 
pokazują, że paralela była nieprzypadkowym elementem jego warsztatu: Historyczna paralela Hiszpanii z Polska, Trzy konstytucje polskie 1791, 1807, 1815, Porównanie dwu powstań narodowych 1794 i 1830, Porównanie Naruszewicza z Karamzinem, Historyczny rozbiór prac Naruszewicza i Czackiego. Lelewel uprawiał więc komparatystykę nie tylko historyczna, jak w przypadku Trzech konstytucji czy Porównania dwu powstań, lecz i literacką. Ta ostatnia najpełniej chyba doszła do głosu w pracy zestawiającej historiografię dwóch wielkich poprzedników Lelewela: Naruszewicza i Czackiego, gdzie znajdujemy porównanie - i to wysokiej próby także narracji historycznej.

U Mickiewicza przykładów ewidentnych, „tytułowych” tak wielu nie ma - prócz np. rozprawy Goethe i Byron oraz kilku późniejszych artykułów z publicystyki politycznej okresu „Trybuny Ludów” - ale nie świadczy to o niewystępowaniu samej metody. Samuel Fiszman, który pisał o komparatystyce jako podstawowym aspekcie jednoczacym prelekcje paryskie i szukał jej przejawów we wcześniejszych tekstach poety, zmuszony był wymienić niemal wszystkie większe dzieła 6 . Jednak nie paralela jako początek komparatystyki tutaj nas interesuje, lecz mniej może oczywisty związek paraleli z myśleniem o historii w kategoriach przestrzennych i z geografią. Najpierw wypadnie zwrócić uwagę na ten rodzaj spacjalności, który trzeba by nazwać przestrzenią tekstu.

Nowatorstwo metody zastosowanej w Historycznej paraleli Hiszpanii z Polska znajduje swoje odbicie w zabiegach formalnych, Lelewel wykorzystał bowiem zapis i druk dwuszpaltowy: po lewej stronie omawiał dzieje Hiszpanii, po prawej zaś ten sam okres w historii Polski. Do podobnego rozwiązania historyk uciekał się później i w innych swoich paralelach, np. w Porównaniu dwu powstań narodowych 1794 i 1830. Jeden $\mathrm{z}$ ostatnich interpretatorów Historycznej paraleli Hiszpanii $z$ Polska, Maciej Ptaszyński, łączy dwuszpaltowość z ikonicznością i formułą „ut pictura poesis":

Dwie równoległe kolumny tekstu są [...] doskonałym świadectwem oddzielności, autonomiczności obu wątków [tj. dziejów Hiszpanii i Polski - D. Z.] Zabieg ten jest wykroczeniem przeciwko sposobom przedstawiania uznawanym implicite w literaturze i przeciwko konwencjom przyjętym $w$ prozie, a już z pewnością w prozie naukowej. Dotyka się tu jednego z podstawowych problemów semiotyki: związku między formą i odniesieniem znaku oraz „problemu referencji wypowiedzi literackich”. Postawę prezentowana przez Lelewela wyraża formuła ut pictura poesis. Zakłada ona, że jednym z celów wypowiedzi literackiej jest malowanie „obrazów w naszych głowach” czy „krajobrazów duszy”.

Nie chodzi jednak o tradycyjnie rozumiane „malowanie słowem” lub o związki z malarstwem, lecz - jak dodaje Ptaszyński - o „specyficzny” rodzaj ikoniczności, który zamiast wyrażania obrazu bądź dźwięku ma na celu oddawanie relacji. Za klasyfikacją Charlesa Sandersa Peirce’a proponuje Ptaszyński mówić nie o obrazie,

6 S. F is z m a n, Komparatystyka $w$ prelekcjach paryskich Adama Mickiewicza. „Pamiętnik Literacki” 1981, z. 2, s. 114-125. Na temat uprzywilejowanej pozycji porównania w prelekcjach i w romantyzmie w ogóle zob. też M. Piwińs ka, Dzieje kultury polskiej $w$ prelekcjach paryskich. W: A. Mickiewi cz, Prelekcje paryskie. Wybór. Przeł., koment. L. Płoszewski. Wybór, wstęp, oprac. M. Piwińs ka. T. 1. Kraków 1997, s. 20.

7 M. Pta szyń ski, Polityka i historia. „Historyczna paralela Hiszpanii z Polska w XVI, XVII, XVIII wieku” Joachima Lelewela. „Przegląd Humanistyczny” 2002, nr 1, s. 25. 
ale o „diagramie”, ponieważ ten właśnie typ ikony nakierowany jest na ilustrowanie relacji pomiędzy elementami przekazu. Badacz nie rozwija owej semiotycznej interpretacji Historycznej paraleli Hiszpanii z Polska, być może ze względu na szczupłość formy artykułu - jednak ze wszech miar godna jest ona głębszego rozważenia i uzasadnienia.

Wypada postawić sobie kilka wstępnych pytań: skąd u Lelewela owo upodobanie do ikoniczności diagramu, na czym polega „specyficzność” właśnie takiej skłonności, czy ma ona charakter epizodyczny, czy też odsyła do trwałej tendencji w historiografii tego autora? Powróćmy na moment do przytoczonej wypowiedzi o dwuszpaltowości jako „wykroczeniu przeciwko sposobom przedstawiania” uznanym w literaturze i historiografii. Ptaszyński miał zapewne na myśli odstapienie przez Lelewela od linearnej czasowości narracji. Jeśli bowiem narrację uważamy za odbicie czasowej natury świata, a podążanie za opowieścią za przejaw temporalności rozumienia ${ }^{8}$, to co oznaczają zastosowane przez Lelewela równoległość i zwielokrotnienie, podwojenie ścieżki narracyjnej?

Przede wszystkim sygnalizują, jak się wydaje, ,przełączenie się” $z$ języka czasu na język przestrzeni, $z$ temporalnego przedstawiania historii na spacjalne sposoby jej ujmowania. Za Jerzym Topolskim trzeba by tu mówić o przejściu z narracji i myślenia diachronicznego na synchroniczne:

W narracjach diachronicznych mamy do czynienia z myśleniem, które często nazywa się linearnym, osadzonym na kauzalnej wizji świata, podczas gdy w narracjach strukturalnych więcej jest myślenia synchronicznego, obrazowego, nasuwającego analogie z percepcją malarstwa ${ }^{9}$.

Lelewel niejeden raz korzystał z rozwiązań ikonicznych i bardzo często - by tak rzec - uprzestrzenniał swoją narrację historyczną, stawiając obok siebie nawet wydarzenia lub zjawiska, które wcześniej musiał „wyjąć” z szeregu diachronicznego (Trzy konstytucje polskie 1791, 1807, 1815, Porównanie dwu powstań narodowych 1794 i 1830, Historyczny rozbiór prac Naruszewicza i Czackiego). Cenił ikoniczność kojarzacą się z potocznie rozumianym diagramem, a więc tabele i tablice chronologiczne (nazywał je niekiedy „letnikami”) oraz mniej oczywiste typy „diagramów”, do których Peirce zalicza również mapy.

Można bowiem uznać, że obraz tekstu Historycznej paraleli Hiszpanii z Polska przypomina mapę. Pokazuje ona jednak nie położenie geograficzne obu krajów, lecz relację wyższego rzędu: bieg ich dziejów względem siebie, "geografię" ich historii. Przedrostek "geo-" nie jest tu całkiem na miejscu, jedyną Ziemią, którą wyobraża owa dziwna mapa, byłaby wyimaginowana planeta historii. Ściślej - wielu historii, w tym wypadku co najmniej trzech: Historii, która jest jedna i wspólna (nazwijmy ją tutaj historią powszechną w modernistycznym, tj. oświeceniowym ujęciu) oraz zawartych w niej równoległych ciągów dziejów Hiszpanii i Polski. Nie jest bowiem prawda, jak sugeruje wspominany tu Ptaszyński, że linie hiszpańska i polska mają

8 O ewolucji narracji historycznej „w kierunku struktury rozumienia działań ludzkich przebiegających w czasie" zob. K. Ro s n e r, Narracja, tożsamość, czas. Kraków 2003, s. 62 n.

9 J. To p ols ki, Jak się pisze i rozumie historię. Tajemnice narracji historycznej. Wyd. 2. Warszawa 1998, s. 120. 
się nigdy nie zbiegnaćc ${ }^{10}$. Lelewel ignoruje prawa geometrii: dwie proste równoległe łączą się w pewnym momencie w tekst jednoszpaltowy - w miejscu, w którym stają się aspektami Historii, procesu powszechnodziejowego. Stanowi ono - narracja zajmująca całą kolumnę - jednocześnie tertium comparationis paraleli. Polska i Hiszpania porównywane są bowiem pod względem tego, jak sytuują się wobec praw, wartości i uwarunkowań rządzących w dziejach, np. wolności i despotyzmu (również w sensie prawnoustrojowym), społecznych ruchów emancypacyjnych czy położenia geopolitycznego.

Wykładanie historii $z$ wykorzystaniem grafiki i geografii nie należało do rzadkości w epoce Lelewela, przeciwnie, był to popularny dość pomysł z zakresu metodyki tej nauki, zwłaszcza w początkowych etapach kształcenia. W pooświeceniowej kulturze oka ten sposób wykładania uchodził za łatwiejszy, stąd właśnie kariera metody poglądowej i wszelkich ikonicznych suplementów do historii narracyjnej. Lelewel jako nauczyciel akademicki ma pośród swoich dzieł artykuły zalecające poprzedzanie nauki historii geografią, a także „diagramami”, tj. wszelkiego rodzaju „tablicami” ${ }^{11}$. Trzeba jednak zaakcentować, że poza niewątpliwym wpływem epoki można posądzać Lelewela o indywidualną skłonność do widzenia synoptycznego, równoczesnego, o upodobanie do synchroniczności.

Współcześni nam historycy podkreślają, że ukuł on termin „historia opowiadająca”, wskazując kategorię czasu jako najważniejszą dla dziejopisarza i kładąc fundamenty pod nowożytną, wielowątkową narrację opartą na doświadczeniach powieści historycznej (Waltera Scotta) i realistycznej ${ }^{12}$. Lelewel jednak nie rozwiną szerzej tej koncepcji, a jego pisarski warsztat nie stał się szkoła „historii opowiadajacej”: jej rzeczywiste narodziny miały miejsce dopiero w pokoleniu następnym, m.in. pod piórem Karola Szajnochy. W tym kontekście warto pamiętać o innej spośród powołanych przez Lelewela kategorii narracyjnych - o „historii opisującej” 13 , której - jak sądzę - on sam był wieloletnim praktykiem, jeśli nie entuzjastą.

$Z$ przywiązania do tej starszej, geograficznej formuły historiografii bierze się prawdopodobnie Lelewelowska preferencja „narracji synchronicznej” i języka przestrzeni, m.in. trwająca przez całe życie pasja kartograficzna. Znajduje ona monumentalne zwieńczenie naukowe w nie przyswojonej dotąd polszczyźnie Géographie du moyen âge (1850-1852), wydanej $z$ atlasem, oraz w opublikowanym anonimowo Albumie rytownika polskiego (1854), który przynosi opowieść na temat Lelewelowskiego pisania historii rylcem i zawiera przebogaty zbiór pięknie kolorowanych map,

Pt a szyń ski, op. cit., s. 26.

Rozpoczynanie edukacji historycznej od geografii jako „niezmiernie do oka przemawiającej” zaleca i uzasadnia J. Le le w el w artykule z r. 1818: O łatwym i pożytecznym nauczaniu historii (w: DzieŁa. T. 2: Pisma metodologiczne. Oprac. N. As s o r od obraj. Cz. 2. Warszawa 1964). Ikoniczne dodatki (mapy, tablice, letnik) towarzyszą Dziejom starożytnym J. Lelew ela (Wilno 1818), najbardziej chyba nowatorskiemu dziełu pod względem dydaktycznym (wręcz interaktywnemu), gdyż wyposażone ono zostało również w instrukcję włączania ich do lektury (s. 9-10).

Pionierską na gruncie polskim koncepcję „historii opowiadającej” Lelewela omawia V. J ulkows k a w pracy Historia dla wyobraźni. Recepcja i interpretacja pisarstwa historycznego Karola Szajnochy (Poznań 2010, s. 250-255).

O rozumieniu „historii opowiadającej” i „historii opisującej” zob. J. Lel e w el, Historia. Jej rozgatęzienie, na czym się opiera. W: Dzieła, t. 2, cz. 1, s. 234-242. 
herbów, pieczęci, monet, elementów architektury. Na innym zaś, tekstualnym, poziomie upodobanie do narracji synchronicznej objawia się poprzez manierę dodawania not, przypisków i zapełniania marginesów w manuskrypcie ${ }^{14}$ - poprzez dążenie, by stworzyć kolejną wersję tekstu bez unieważniania poprzedniej. Typowym przykładem podobnej strategii narracyjnej jest postać, decydującego dla Lelewelowskiej teorii gminowładztwa, tekstu Uwagi nad dziejami Polski i ludu jej, który ukazał się jako autonomiczny, ale w zamyśle był również - o czym świadczy przedmowa - ciaggiem uzupełnień do dużo wcześniejszej syntezy Dzieje Polski potocznym sposobem opowiedziane:

Rozdziały tych uwag mogą wejść między rozdziały opowiadanych dziejów, tworząc z nimi jednę całość wspólnie tęż samę do czytania roztaczają osnowę. Dość jest przebiec rozdziały opowiadanych dziejów, a po każdym okresie wziąść rozdziały uwag, które jak ciag dalszy opowiedziane rozważają, tak że rozdziały obu plączą się i schodzą w jeden wątek do końca. Wskazać rozdziałów plecionkę nie zaniedbuję $^{15}$

Lelewel zatem oczekiwał, że czytelnik będzie miał przed sobą oba dzieła i podczas lektury tę, jak sam mówił, „plecionkę” starego tekstu z nowym ułoży sobie w całość - od siebie dodał tylko instrukcję, w którym miejscu je łączyć. Odbiorcy przypadł więc obowiązek wytworzenia diachronicznej formy z dwóch synchronicznych względem siebie ciagów narracyjnych, dziejów Polski i dziejów ludu - w uproszczeniu: politycznego i społecznego. Co ciekawe, obowiązek ten nie został z odbiorcy zdjęty w kolejnych wydaniach, Lelewel bowiem nie decydował się na połączenie obu części syntezy i nadal publikował Uwagi i Dzieje Polski jako osobne utwory. Trudno to jednak oceniać $z$ dzisiejszej perspektywy - romantyzm był epoką wielkich czytelników i kiedy Lelewel ogłaszał w „Tygodniku Wileńskim” rozprawę Jakim ma być historyk (1818), to nie tylko polemizował z lekceważącą historię postawą Jana Śniadeckiego ${ }^{16}$, ale i popularyzował pogląd o społecznej misji „dziejarza”, która w pewnym sensie podejmował każdy odbiorca jego dzieł.

Dzisiaj powiedzielibyśmy, że sygnalizowane tu zabiegi są interesującą rewoltą przeciw dyktatowi narracji temporalnej, jednonurtowej, oraz przeciwko konieczności wyboru jednej, ostatecznej wersji powstającego tekstu, która przekreśla wcześniejsze. Oczywiście, rewoltą katastrofalną w skutkach dla edytora, jeśli nie jest on wyposażony w multimedialne środki przekazu, a w rezultacie również dla uczonego i twórcy, czego autor nie wznawianych od XIX w. Uwag nad dziejami Polski i ludu jej może być smutnym przykładem. W epoce Lelewela podobna technika narracyjna wynikała raczej - nie licząc emigranckich powodów sięgania po rozwiązania prowizoryczne - z szukania dopiero formy dla nowego odczucia dziejów, które Reinhart Koselleck opisuje jako wszechwładne, progresywne, nie dające się zatrzymać ${ }^{17}$.

Część np. dopisków do prac metodologicznych wydała N. Assorodobraj w postaci osobnego tekstu, nazywając je Notatami do historyki, wtręty z marginesów przenosiła w miarę możliwości do przypisów, zob. Lele we 1, Dzieła, t. 2, cz. 1, s. 209-232 i s. 484-486 (Komentarze).

15 J. Le lew el, Uprzednia myśl, czyli słowa do poszukiwań wstępne. W: Polska, dzieje i rzeczy jej. T. 3. Poznań 1855, s. 28.

16 Zob. Lelewel, Dzieła, t. 2, cz. 2, s. 687 (Komentarze).

17 R. Koselleck, Semantyka historyczna. Wybrał, oprac. H. Orłowski. Przeł. W. Kunicki. Poznań 2001, s. 75-106. 
Zatem również nie pozwalające się unieruchomić w tekście, reprezentacji dezaktualizującej się już w momencie powstawania, bo nie potrafiącej sprostać szybkości zachodzących zmian. Nowożytne pojęcie dziejów zerwało, jak pokazuje Koselleck, $\mathrm{z}$ toposem historia magistra vitae - czego bowiem historia mogła uczyć, skoro nic w niej nie występowało dwa razy? Owa jednokrotność wydarzeń również zachęcała - jak sądze - do narracji tymczasowych i roboczych, do prac o statusie „materiałów do historii”, które raczej dają wgląd w niezakończony żywy proces dziania się, niż prezentują ostateczny jego rezultat. Ten $\mathrm{z}$ założenia był sprawa przyszłości i ona właśnie stała się podstawowym punktem odniesienia w w. XIX, co doskonale wyczuwamy także w literaturze romantycznej, w jej futurystycznym i profetycznym ukierunkowaniu. A zarazem niepewność wynikająca $z$ progresywizmu dziejów i fragmentarycznych narracji o nich wytwarzała potrzebę ujęć całościowych. Na niemieckim gruncie prowadziło to do rozwoju systemowej, idealistycznej filozofii dziejów, w Polsce zaś raczej znalazło zaspokojenie w bardziej pragmatycznych ujęciach - syntezach historycznych (literackich i historiograficznych), które w romantyzmie przeżywają swój rozkwit (np. Dzieje Polski potocznym sposobem opowiedziane, Polska odradzajaca się, Uwagi nad dziejami Polski i ludu jej Lelewela, prelekcje paryskie Mickiewicza) ${ }^{18}$. Niestety, pamięć o tym wspólnym dla literaturoznawstwa i historiografii typie narracji historycznej, bogatym w odniesienia historiozoficzne i publicystyczne (oraz polityczne) na gruncie mickiewiczologii dziś już zaginęła, ustępując miejsca ostrym podziałom między obiema dziedzinami.

Co do owej bardzo grubą kreska zarysowanej zmiany w odczuwaniu dziejów wypada dodać, że ogranicza ona reprezentatywność uwagi Kubackiego o paralelizmie (podobieństwie) jako istocie historyzmu romantycznego. Zasadność myślenia przez analogię, w kategoriach podobieństwa musi być opatrzona zastrzeżeniami $z$ tego samego powodu, $\mathrm{z}$ jakiego dokonał się rozpad Cycerońskiego toposu, a raczej jego istotna redefinicja, bo z analiz Kosellecka wynika, że - naturalnie - historia nadal czegoś uczy, np. kreatywności, ale już nie poprzez gotowe egzempla. Tak samo z paralelizmem: Lelewel kładł nacisk na to, by w miarę możliwości zestawiać wydarzenia $z$ tego samego czasu (rzeczywiście równoległe), lecz pamiętać, że porównywanie prowadzi $z$ reguły do odkrycia różnic, nawet jeśli na pierwszy rzut oka dostrzegamy podobieństwo.

Powróćmy teraz do „plecionek” i sprawy narracji. Aby dać wyraz historyczności rozumienia, Lelewel utrwalał zapewne poszczególne jego momenty, $\mathrm{z}$ góry godząc się na ich dezaktualizację i konieczność suplementowania. Zachowywał wcześniejsze wersje tekstu, traktował je jako fragmenty „stającej się” opowieści i dążył do stworzenia wirtualnej formy - w wyobraźni czytelnika - która obejmowałaby ów rozciagnięty w czasie palimpsest (np. historii Polski) w całej jego przestrzenności. Jako sposób prowadzenia wywodu naukowego może się to wydawać dziwaczne i nierozważne, mieści się przecież w literackiej kulturze epoki. Niezapleciona „plecionka" przypomina mianowicie alinearną kompozycję Dziadów, w której nie spo-

18 Zob. J. Adamus, Monarchizm i republikanizm w syntezie dziejów Polski. Łódź 1961, s. 12-90 (tytuł mylący, książka zawiera uwagi również o literackiej syntezie historycznej, w tym $z$ okresu romantyzmu). - M. W i e r z b i c k a, Dawne syntezy dziejów Polski. Rozwój i przemiany koncepcji metodologicznych. Wrocław 1974, s. 18-46. 
sób diachronicznie uporządkować poszczególnych części ani z porządkowania zupełnie zrezygnować. Tego rodzaju podobieństwo emigracyjnych narracji historycznych Lelewela do literackich konstrukcji dramatycznych oraz do malarstwa mogłoby z kolei świadczyć o inspirowaniu się romantyczną formą otwartą, Goetheańską i Mickiewiczowską ${ }^{19}$, o czerpaniu przez profesora $z$ pisarskich dokonań jego byłych uczniów.

Upodobania do synoptyczności nie warunkowała jednak tylko indywidualna wyobraźnia Lelewela, łączyło się ono z wykładem historii powszechnej, którą łatwiej było uzmysłowić sobie w postaci narracji synchronicznej niż poprzez samą diachronię. Warto przypomnieć, na jak karkołomne rozwiązania zdecydował się Ignacy Krasicki - w jednym tekście, Historia na dwie księgi podzielona, postanowił fabularnie opowiedzieć dzieje świata: jego bohater musiał być nieśmiertelny, regularnie zażywać balsam odmładzający i nieustannie podróżować ${ }^{20}$. Naturalnie, fabularność stwarza odrębne wymagania, ale $z$ troski o jedność i spójność narracji nie może przecież zrezygnować żadne przedstawienie przeszłości. Innym wyjaśnieniem inklinacji do synchronii wydaje się Lelewelowskie pojmowanie czasu - w wykładach wstępnych do dziejów powszechnych wprowadzał on studenta w świat rozmaitych jego miar, a więc zupełnie umownego, relatywnego jego postrzegania w zależności od epoki i kultury:

$Z$ różnego narodów przyzwolenia powstają godziny, dni, miesiące i lata sztuczne, czyli urządzone (civiles, artificiales). Etruskowie i niektóre w Italii narody liczyły lata dziesięciomiesięczne (mające dni 304). Wszakże powszechnie usiłują się narody trzymać miesięcy i lat księżycowych lub słonecznych. Arabowie, a za nimi wszyscy mahometanie, liczą lata księżycowe (mające dni 354), które żeby nie chybiały biegu księżyca, przestępne lata są rozrzucone w cyklu księżycowych $30^{21}$.

I od tej zatem strony historia powszechna składała się $\mathrm{z}$ wielu poszczególnych historii, sam czas nie występował bowiem jako zjawisko singularne, lecz pod wieloma postaciami. Zwłaszcza przez studentów-,_Litwinów”, nawykłych do życia według dwóch kalendarzy, gregoriańskiego i juliańskiego, wielość czasu i historii musiała być traktowana najzupełniej naturalnie.

Trzeba przyznać, że pomysł „obrazkowego” przedstawiania historii i narracji historycznej nie od razu przypadł Lelewelowi do gustu. W roku 1806 na posiedze-

19 O pogłębionej lekturze tekstów Mickiewicza można mówić w odniesieniu do okresu wileńsko-kowieńskiego, kiedy Lelewel był cenzorem Dziadów i Grażyny. Na temat powstających przez długie lata form twórczości Goethego, ich podstawy antropologicznej oraz romantycznej formy otwartej zob. M. J a ni o n, Czas formy otwartej. Warszawa 1984, s. 291-298. - M. J a n i o n, M. Żmi g r o d z ka, Odyseja wychowania. Goetheańska wizja człowieka w „Latach nauki i latach wędrówki Wilhelma Meistra". Kraków 1998, s. 27-39.

20 A i tak kwituje się ten utwór jako „zabawny i dziecinny galimatias z historii powszechnej”, „galopadę ponad zawrotnymi przepaściami czasu”, wreszcie „śmiertelnie nudną historię”. Zob. P. C a zi in, Ksiażę biskup warmiński Ignacy Krasicki 1735-1801. Przeł. M. M r o z in s k i. Posłowie oprac. i bibliografię uzup. Z. Goli ń s ki. Olsztyn 1986, s. 196-198. Lelewel znał Historię Krasickiego, a nawet odnajdował zmyślone przez niego postaci „historyczne” na tablicach chronologicznych z epoki - zob. J. Lele w e l, Tablice chronologiczno-historyczne [...]. W: Polska, dzieje i rzeczy jej, t. 18, cz. 2 (1865), s. 42.

21 J. Lel e w el, Wykład dziejów powszechnych. W: Dzieła, t. 3: Wykłady kursowe z historii powszechnej w Uniwersytecie Wileńskim 1822-1824 (Oprac. M. H. S e r e j s ki. Warszawa 1959), s. 102-103. 
niu Towarzystwa Filomatycznego - poprzednika organizacji filomackiej założonej przez „rówieśników Mickiewicza” - czytał on recenzję o wymownym tytule Uwagi nad tablica dziejopiska Fryderyka Strass wyszła w Berlinie w r. 1803 pod tytułem „Potok czasu” i nad ksiażeczka do jej wyświetlenia przyłączona. Wymownym, bo tytuł wskazuje na „przyłączenie” książeczki do tablicy, nie na odwrót - w obyczajach epoki częstą była więc sytuacja, gdy tekstualne słowo miało tylko towarzyszyć przekazowi ikonicznemu. Strass był z wykształcenia filologiem i teologiem, uczniem pluralisty Friedricha Augusta Wolfa, znanego ze sporu o Homera, i w swojej pracy pedagogicznej wykorzystywał graficzne przedstawienia historii powszechnej. Niezwykłość będącej jego dziełem „tablicy dziejopiskiej” ${ }^{22}$ leży w jej malarskim charakterze, łączy ona bowiem synchroniczność i schematyzm tabeli z figuratywnym nieomal obrazkiem u góry. Widać tam rozświetloną kulę (Słońce?) i pod nią ciemne, deszczowe chmury (pradziejów?), z których wypływają pokolorowane strugi (historii). Lelewel tak opisuje tablice Strassa Potok czasu:

Sama tablica jest pod tytułem Strom der Zeiten (Potok czasów) [zatem tutaj „czasów”, nie „czasu” - D. Z.]. Dziwne wyobrażenie! z chmur płyną rzeki, a rzeki czasów, rzeki w wielu miejscach niknące i siebie, że tak powiem, pożerające. [...] Podobniejsza do prawdy, żeby jakakolwiek wymyślona roślina miała swój korzeń i z niego wychodziła, aniżeli gdyby potoki bez żadnych po górach spadków z chmur płynęły ${ }^{23}$.

Wyobrażenie czasu jako spadającego z nieba „potoku” nie znalazło uznania w oczach Lelewela, wolał on już najdziwniejsze nawet drzewo (zastosował je inny autor tablic, krytykowany z kolei przez Strassa), które by „przyzwoicie” z korzenia wyrastało. Jednak zastrzeżenia budził chyba nie tyle sam „potok” czy też - jak się w tej recenzji dalej mówi - „rzeka”, ile owo nieprawdopodobieństwo spadania prosto z chmur; zresztą na tablicy Strassa historia w postaci strumieni czasu spływa na ziemię raczej jako kolorowy deszcz niż jako „potok”. Źródłem całego dysonansu wydaje się górna, malarska część tej tablicy, z burzowymi chmurami, z których wyłaniają się w porządku narastającym owe „strugi czasu”: od pojedynczego strumyka, przez rzeki, aż do morza. Ta część ryciny nie była zapewne w intencji Strassa jedynie ozdobnikiem, raczej alegorycznym wstępem do rozumienia historii - na analizę tej alegorii nie ma tutaj miejsca - lecz w odbiorze Lelewela wywoływała ona wrażenie braku realizmu.

Później, w r. 1820 Lelewel napisał swą dwuszpaltową Historyczna paralelę Hiszpanii $z$ Polska, ale jej nie wydał; uczynił to dopiero w czasie powstania listopadowego, przedtem jednak, w r. 1828, wyszło inne jego dzieło, rodzaj graficznej tablicy chronologicznej albo mapy: Dziesięć uptynionych wieków dawnej Polski oraz krajów i mocarstw, z którymi ściślejsze zwiazki lub bliższe stosunki miała ${ }^{24}$.

Tablicę Strom der Zeiten F. Stra s s a można dziś obejrzeć na stronie internetowej pod adresem http://daten.digitale-sammlungen.de/ db/bsb00003029/images/ (dostęp: 11 XI 2012).

23 J. Le lew el, Uwagi nad tablica dziejopiska Fryderyka Strass wyszła w Berlinie w r. 1803 pod tytutem „Potok czasu” i nad ksiażeczka do jej wyświetlenia przyłaczona. W: Polska, dzieje i rzeczy jej, t. 18, cz. 2, s. 7.

24 Rok później ukazała się mała książeczka objaśniająca tablicę-mapę: J. Le le w el, Dziesięć upłynionych wieków dawnej Polski, czyli chronologia do obrazu dziejów polskich. Warszawa 1829. Układ tekstu jest tu również przemyślany, dzieli się on na dwie pionowe kolumny: w pierwszej umiesz- 
Jak wynika już z tytułu, pomysł Lelewelowskiej „kartografii czasu” jednak coś Strassowi zawdzięcza: przynajmniej skojarzenie „upłynionych wieków” z graficznym obrazem płynącej wody. Ona tutaj rzeczywiście nie spada z chmur czy też z nieba, Lelewel nie dąży aż tak konsekwentnie do efektu realności i w rezultacie jego tablica jest bardziej scjentyficzna i umowna. Polski uczony zachowuje wszelako Strassowski kierunek biegu dziejów, a więc z góry na dół, co można wykładać różnie. Z jednej strony, gradacja wód zdaje się oznaczać postęp i sytuować obu kartografów czasu, zwłaszcza zaś Strassa, bliżej stanowiska „nowożytniczego” niż „starożytniczego" 25 . Z drugiej jednak - zastosowana aksjologia przestrzeni (góra-dół) wskazuje na postrzeganie procesu historycznego, szczególnie z polskiej perspektywy, w kategoriach degeneracji, a nie postępu bądź rozwoju.

U Lelewela historia płynie, tworząc rzeki, strumyki, rozlewiska i jakby połączone ze soba jeziora. Plan podstawowy diagramu czy mapy - może „histomapy” (takiego pojęcia używa się w „kartografii czasu” ${ }^{26}$ ) - stanowią pionowe strugi dziejów biegnące równolegle względem siebie, by się miejscami łączyć czy też, jak wyraził się Lelewel w recenzji tablicy Strassa, „pożerać”. Wewnątrz są one wypełnione imionami władców, gdy zaś dany król panuje równocześnie w dwu sfederowanych państwach, jak Zygmunt August - wtedy strumienie historii polskiej i litewskiej zlewają się. Mamy więc następujące strugi dziejów w punkcie wyjścia, przed r. 900: państwo Franków, Czechy, Morawy, Polska, Ruś i Skandynawia, a w punkcie dojścia u dołu mapki: Turcja, Austria, Prusy, Rosja, Szwecja i Dania. Niektóre państwa zniknęły, pozostałe podzieliły się, „zlały się” z innymi bądź zostały „pożarte” (Polska z Litwa).

Tak widziana historia nie ma charakteru linearnego, lecz wielonurtowy, równocześnie jednak - ponieważ mieści się na jednej karcie, a nurty dynamicznie łączą się i rozdzielają - nie zrywa $z$ wyobrażeniem wspólnych, uniwersalnych dziejów. Historia Lelewela (oddajmy sprawiedliwość jego woli odróżnienia się od Strassa) przypomina nie tyle kolorowy deszcz lejący się z nieba, ile krainę wielkich jezior. Powstaje pytanie, czy wpuszczony w dwie kolumny tekst Historycznej paraleli Hiszpanii z Polska, kolumny zasadniczo odrębne, lecz od czasu do czasu schodzące się, można uznać za tekstualny wariant owej metafory historii jako pejzażu z rzekami i jeziorami. Jeśli tak, to Lelewel, wyzwalając się spod presji tradycyjnego układu tekstu, osiagnął zarazem efekt praktyczny i estetyczny: rodzaj narracyjnej tablicy chronologicznej połączonej z metafora historii.

Warto rozważyć, czy Mickiewicz przejął coś z Lelewelowskiego „paralelowania” graficznego. Wydaje się, że tak - lecz poeta nie tworzył tekstowych metafor, raczej nimi myślał. Ksiegi narodu polskiego i pielgrzymstwa polskiego sa zapisane w tradycyjnej, linearnej narracji, ale na potrzeby analizy Zofia Stefanowska w swej znanej książce Historia i profecja nadała im postać dwukolumnową: po lewej stro-

czone sa daty i wydarzenia historyczne, w drugiej - „pisarze dziejów” (historycy, literaci, malarze, astronomowie, geografowie, np. F. Smuglewicz, W. Bogusławski, K. Wyrwicz, ks. M. Poczobutt. Zatem była to równoległa do kroniki wydarzeń historia piśmiennictwa i kultury. 
nie umieściła zdania odnoszące się do dziejów męki Pańskiej, po prawej - relacjonujące rozbiory Polski ${ }^{27}$. Stefanowska poprzez zabieg $\mathrm{z}$ zapisem w dwu kolumnach pokazywała istotę wykładu figuralnego - wybrane fakty $z$ historii Polski były przez Mickiewicza interpretowane w perspektywie przyszłości, która, przynosząc wypełnienie zapowiedzi, nadawała minionym wydarzeniom sens. Operacja Stefanowskiej ujawnia jednak przede wszystkim inną rzecz: że podstawą myślenia Mickiewicza jest paralela historyczna, porównanie dziejów Polski do dziejów Chrystusa, ponieważ właśnie historia Jego męki i zmartwychwstania dostarczyła modelu figuralizacji $^{28}$.

Zatem paralela właśnie, stałe odnoszenie wydarzeń $z$ historii Polski do żywota Chrystusa - zamkniętego (spełnionego) i wyprzedzającego polskie wydarzenia umożliwiła figuralność i uruchomiła profecję. Ukryty paralelizm rządzi też widzeniem Księdza Piotra; niepodobna zrozumieć tej sceny bez przywołania w myśli kolejnych stacji Męki Pańskiej - na jej schemacie, niczym na niewidzialnym prawidle, modelowane sa przez Mickiewicza obecne i przyszłe dzieje narodu polskiego. Przedtem synchronizował on poezję przeszłości z poezją przyszłości (Goethe i Byron), dawnych Litwinów z Maurami, a Zakon Krzyżacki z Hiszpanią czasów rekonkwisty (Konrad Wallenrod), w czym $n b$. można by doszukiwać się bezpośredniego wpływu Lelewelowskiej Historycznej paraleli Hiszpanii z Polska. To paralele jawnie wpisane w teksty, a maja jeszcze ukryte piętra, na których właśnie przywoływany na wstępie Kubacki umieszczał istotę historyzmu romantycznego. Mesjanizm, zestawienie dziejów Chrystusa i Polski, pojawił się u Mickiewicza dopiero po powstaniu listopadowym i mógł szokować śmiałością skojarzeń, ale samo „paralelowanie” było przez niego stosowane znacznie wcześniej i trudno w nim upatrywać coś wyjątkowego. Doskonale się bowiem mieściło w kulturze historycznej owej epoki, zarówno tej naukowej i analitycznej (Lelewelowskiej), jak i ulicznej, bo przecież legendarne listopadowe hasło przypisywane Leonardowi Chodźce, „Słowo stało się ciałem, a Wallenrod Belwederem" ${ }^{29}$, również było paralelą. Sądzić wręcz można, że powszechność, a także racjonalność myślenia opartego na paraleli były istotnymi przesłankami szybkiego przeniknięcia mesjanizmu do świadomości Polaków.

Wolno więc uznać, że poeta, budując mesjanistyczny wykład historii w Księgach narodu polskiego i pielgrzymstwa polskiego, wcześniej zaś w III części Dziadów, mógł podążać tropem tekstu (i metody) swojego wileńskiego profesora, z którym właśnie po latach spotkał się w Paryżu - tekstu zupełnie niedawno wydanego w powstańczej Warszawie, choć pochodził on jeszcze z 1820 roku. Zwłaszcza że paralelizm był - jak go nazywał Kubacki - „dzielnym środkiem agitacyjnym”, który doskonale sprawdził się w Historycznej paraleli, a potem potwierdził swoją publicystyczną wręcz skuteczność w Księgach narodu polskiego. Podobieństwo między

Z. St ef a n ow s ka, Historia i profecja. Studium o „Księgach narodu i pielgrzymstwa polskiego”. Warszawa 1962, s. 46.

Kiedy jednak posługujemy się zaproponowanym przez Stefanowską pojęciem „wykładu figuralnego” i akcentujemy parataksę, stylizację biblijną, a nie paralelizm, powstaje wrażenie, jakby Mickiewicz odwoływał się do sposobu myślenia biegunowo odmiennego od naukowego historyzmu, choć autorka Historii i profecji podkreślała związek Ksiag z koncepcjami oświeceniowymi.

Cyt. za: M. J ani o n, Tragizm „Konrada Wallenroda”. W: Romantyzm. Studia o ideach i stylu. Warszawa 1969, s. 10. 
obu twórcami zdaje się zachodzić w wielu punktach, np. także u Lelewela równoległości zapisu historii Hiszpanii i Polski towarzyszą analogiczne zwroty stylistyczne i porządek syntaktyczny:

Cztery korony półwyspu Pirenejskiego (Kastylia, Aragonia, Granada, Nawarra) składają Hiszpanię [...].

Szło Francji o Oboją Sycylię i Mediolan, który Hiszpanie posiedli; szło o Nawarrę i Burgundię.

To duch najazdu i podboju Ludwika XIV, Napoleona, Ludwika XVIII upokorzył i podporządkował Hiszpanię. Chce oprzeć swoje granice o Ren, pragnie odtworzenia dominacji Franków, marzy o Zachodnim Imperium dawnego Rzymu; myśli o ujarzmieniu świata.
Cztery krainy (Polska, Litwa, Prusy i Mazowsze) [...] składają Polskę [...]. [L 24]

Szło Moskwie o posiadłości aż do Berezyny, o Inflanty, które się z Polską połączyły; szło o księstwa i rzeczypospolite ruskie. [L 25]

To duch najazdu i podboju Katarzyny II, Aleksandra, Mikołaja upokorzył i rozdarł Polskę. Chce oprzeć swoje granice o Niemen i Bug, a nawet o Wisłę, marzy o imperium słowiańskim i pragnie odtworzyć Wschodnie Imperium nowego Rzymu (Konstantynopola); myśli o ujarzmieniu świata. [L 60]

Ostatnia para fragmentów pochodzi z tej części paraleli, która powstała na emigracji - Lelewel w pełni podtrzymuje w niej młodzieńczą poetykę, natomiast nowa jest znacznie ostrzejsza niż w okresie przedlistopadowym ocena Francji, potraktowanej teraz zupełnie symetrycznie w stosunku do Rosji.

Czy Lelewel w Historycznej paraleli był profetyczny? Na pozór oczywiście nie, prócz podobieństw istnieją bowiem różnice między „paralelowaniem” u Lelewela i u Mickiewicza. Najszybciej dostrzegalną odmiennością jest to, że porównania pierwszego autora formułowane sa explicite, drugiego - implicite. Kolejna polega na tym, iż Mickiewicz jedną część paraleli sytuuje w wymiarze historycznym, drugą zaś poza nim, podczas gdy Lelewel ogranicza się do planu ziemskiego. Jeszcze inna odmienność sprowadza się do celu porównywania: Lelewel zawsze podkreślał, że ta metoda służy mu do wychwytywania różnic między zestawianymi elementami ${ }^{30}$, natomiast u Mickiewicza są one wyraźniej połączone podobieństwem, ba, podobieństwem posuniętym nieomal do tożsamości. Można bowiem powiedzieć, że Mickiewiczowska paralela między dziejami Chrystusa a historią Polski zmierza do zlania się obu „potoków czasu”, a punktem ich przecięcia się byłaby metafora „Polska Chrystusem narodów”. Charakterystyczne, że u Mickiewicza nie pojawia się ona literalnie, jest tworem recepcji, paralelą do formuły „Polska Winkelriedem narodów” z Kordiana. To czytelnicy zatem (już Słowacki?) zadecydowali o herezji połączenia dziejów Polski z historią świętą w jeden strumień - Mickiewicz je rozróżniał.

Ale umieszczenie paraleli w planie ziemskim nie wyklucza jej związku z przewidywaniem przyszłości i warto $z$ tej perspektywy spojrzeć na decyzję publikacji Historycznej paraleli Hiszpanii z Polska podczas powstania. Przyjęło się uważać za oczywiste wytłumaczenie, że Lelewel zdecydował się na druk, chcąc skorzystać z likwidacji cenzury - samo to zresztą dowodziłoby, że w jakieś niecenzuralne przesłanie utwór był wyposażony w przekonaniu samego autora, skoro nie próbował 
on wcześniej forsować druku. W wariancie z r. 1820, podobnie jak potem uczyni Mickiewicz w przedmowie do Konrada Wallenroda, Lelewel przeczył jakimkolwiek związkom Historycznej paraleli, zakończonej opisem „niemocy i upadku” obu państw, z aktualnymi wydarzeniami i z przyszłością: „Czyli kto z tego jaką wróżbę przyszłości wywiązywać zdoła, czyli już tak jednostajna kolej państw już wykończona - to z obrębów historycznych badań wychodzi. Przeszłość je tylko zajmuje” (L 20). O tym, że owej „jednostajnej kolei” historii polskiej i hiszpańskiej (w uproszczeniu: ich współbieżności, porównywalności) bynajmniej za „wykończoną” autor nie miał nawet w r. 1820, a wybuch powstania listopadowego potwierdził tylko jego intuicje - dobitnie świadczy kontynuacja Historycznej paraleli z połowy lat trzydziestych:

Niezadowolenie, wzrastające $z$ dnia na dzień, wybuchło powstaniem w Hiszpanii, zapełniło więzienia w Polsce. Niezadowoleni musieli porozumieć się, zorganizować, przekazać swoje idee i rozpowszechnić je, jedynym sposobem, aby doprowadzić do tego, były sekretne środki i konspiracja [...].

Powstanie hiszpańskie 1820 roku poprzedziło o prawie 10 lat powstanie w Polsce, które wybuchło pod koniec 1830 roku; obydwa miały podobne rozwiązanie za sprawą tych samych błędów. [L 63-64]

Wypowiedź ta potwierdza domysły badaczy Lelewela, że samo napisanie Historycznej paraleli miało związek $z$ wybuchem powstania w Hiszpanii w r. $1820^{31}$, wspierało się też - dodajmy - na ogólnym przeświadczeniu polskiego historyka, iż „zachód nadal wyprzedza wschodnią część Europy” (L 68) ${ }^{32}$. Cóż za satysfakcję musiał więc odczuwać autor zestawienia na papierze losów Hiszpanii i Polski, kiedy 10 lat później Warszawa rzeczywiście poszła w hiszpańskie ślady. Jak się wydaje, powstańcza publikacja Historycznej paraleli mogła być wyrazem widocznej w utworze wiary, że i tym razem - przy całej ,jednostajności” dziejów - Polska odróżni się od zniewolonej Hiszpanii ${ }^{33}$ zwycięstwem wolności.

Lelewelowskie prognozowanie przyszłości, którego zewnętrznym wyrazem jest przewidywalność prostej równoległej do innej linii, nie jest, rzecz jasna, profetyzmem, nie wypływa bowiem $z$ Boskiej inspiracji. Wynika $z$ racjonalnego rozpoznania mechanizmów procesu dziejowego, wedle którego - jak zobaczymy dalej - progres historii, bieg dziejów stanowi źródło podobieństw, natomiast „położenie miejscowe” oraz „stan i natura narodów” przyczynę różnic. Narody są zatem poddane tym samym procesom i przemianom społecznym, lecz inaczej je przechodzą - powstanie hiszpańskie zapowiadało więc polską insurekcję, ale mogła mieć ona odmienny, pomyślny przebieg. Przewidywanie tego, co nastąpi, w wypadku Lelewela wypływa jednak również z jego zadziwiającej intuicji czasu, którą historyk umieszcza w zakończeniu dopisanego już w Belgii fragmentu Historycznej paraleli:

Proszę mi wybaczyć, że obróciłem mój wzrok ku przyszłości. Kiedy jest się na końcu przeszłości, wchodzi się jednocześnie w czas przyszły, który niezwłocznie następuje. Teraźniejszość nie istnieje dla nas, jest tylko stykiem przeszłości z przyszłością, chwilą niebyłą, niespostrzegalną, nieuchwytną, która wciąż wymyka się myśli ludzkiej. [L 68]

Zob. A. Śli wiń s ki, Joachim Lelewel. Zarys biograficzny. Warszawa 1932, s. 105-106. - S e r ejski, op. cit., s. 381.

32 Tutaj jeszcze historyk nie zwalcza przekonania, że Polska jest młodsza cywilizacyjnie - być może, właśnie ze względu na chęć podtrzymania prognostycznej wymowy paraleli.

33 Na stronniczość w Lelewelowskim widzeniu Hiszpanii zwraca uwagę Kieniewicz w swoim wstępie do nowego wydania Historycznej paraleli (L 8). 
Zatem wszyscy jesteśmy ludźmi przyszłości, choć wydaje się, że „dla nich” Polaków w XIX w. - skazanie teraźniejszości na nieistnienie musiało być szczególnie istotne i obiecujące.

Związek Historycznej paraleli Hiszpanii z Polską z mapą nie sprowadza się tylko do ikoniczności narracji, która układa się w specyficzną metaforę historii czy też we wspominana już kartografię czasu. Wiele wskazuje na to, że genetycznym źródłem pomysłu na to dzieło mogło być doświadczenie kartograficzne, studiowanie rzeczywistej mapy Europy. Wyjawiając, skąd czerpał inspirację do zastosowania metody porównawczej, Lelewel powołuje się ogólnie na wzory starożytne:

Czytamy w starożytności paralele osób wtedy tworzone, kiedy rzymscy pisarze więcej baczności do charakterów ludzi zwrócili. Żeby charakteryzować dzieje narodów, żeby je paralelować - na to starożytność nie wpadła, albowiem nie dostawało jej wyższych i ogromniejszych widoków, jakie dziś historię zajmują. Może znane przez nich dzieje niedostatecznym jeszcze były dla pisarzów doświadczeniem. [L 19]

Nie wiadomo, jakich konkretnie pisarzy Lelewel miał na myśli, prawdopodobnie zbyt szczupłe „widoki” wiążą się z krótką jeszcze u starożytnych perspektywą historyczna, która ograniczała zakres dziejów do spraw „obecności”, teraźniejszości. Perspektywę („,widok”) wydłużył upływ czasu, powiększając tym samym „doświadczenie” ludzkości. Jednak „wyższy i ogromniejszy widok” zdaje się zależeć nie tyle od długości dziejów, ile od punktu, z którego je oglądamy:

Jeżeli [...] zmienności [władców] w ostatnich trzech wiekach szukać chcemy i z wyższego stanowiska na ogół Europy pozieramy, zastanowić może, jak pod koniec XV wieku, kiedy się z jednej strony dźwiga Francja, z innej Moskwa, wtedy z jednej strony Hiszpania, z innej Polska zawiązują się w państwa wielkie. W wieku XVI z jednej strony Hiszpania, z innej Polska są przeważne. Pośrodku Europy Rzesza Niemiecka i w niej odrywający się od Rzymu chrześcijanie. Gdziekolwiek język niemiecki, tam i wyznanie protestanckie. Hiszpania z jednej strony, Polska z drugiej zostały wierne Rzymowi, katolickie, nad znaczną częścią Niemców protestantów panujące. [L 20]

O jakie „strony” i „środek” czego Lelewelowi tutaj idzie? Najprawdopodobniej o strony świata na mapie Europy z państwem niemieckim „pośrodku” . „Pozieramy” zatem na historię Europy z „wyższego stanowiska” - dosłownie! - kiedy patrzymy na jej mapę. Wtedy bowiem zdolni jesteśmy spojrzeć $z$ góry, to zaś spojrzenie ujawnia rzeczy niewidoczne $z$ poziomej perspektywy, ograniczonej do wąskiego kręgu najbliższej współczesności. („Wylatywanie nad poziomy”, chęć poszerzenia „świata koła, które [człowiek] tępymi zakreśla oczy" - to język Ody do młodości, ale podobne doświadczenie można przeżyć nad mapa, w której tajniki wprowadza charyzmatyczny nauczyciel.) Mapa, mówiąc skrótem, pokazuje przede wszystkim sytuację geopolityczną danego miejsca i możliwe scenariusze jej rozwoju, np. nietrudno było wyczytać z mapy doktrynę tzw. „zaokraglenia” stosowaną w Europie w okresie rozbiorów Polski, a i sam akt rozbioru od początku był kojarzony z rozrywaniem jej kartograficznego ciała. Ponieważ położenie danego kraju czy miejsca nie zmienia się diametralnie, $z$ mapy uciec nie sposób, ujawnia więc ona stałą sytuację określonego terytorium $\mathrm{w}$ historii, odsłania indywidualny los narodu. Stąd już tylko krok do związku mapy z przewidywaniem przyszłości.

Lelewel kojarzył różnice $z$ mapą i lokalizacja, tak jak podobieństwo łączył Z wpływem czasu i wspólną, powszechną właśnie historią. Kończąc przedmowę do Historycznej paraleli, pisał: 
My z tego, co się dostrzec udało, niniejszym sprawę zdając, rozważać będziemy, jak z ogólnego stanu związku i stosunków w chrześcijaństwie i polityce Europy właściwie wynikaja podobieństwa wielkości, poniżenia i upadku, jak zaś bardzo różny stan i natura tych dwóch narodów [tj. polskiego i hiszpańskiego], bardzo odmienne ich miejscowe położenie jest zrzódłem odcieni w tym podobieństwie, jest przyczyną wielkich różnic. [L 21]

„Położenie miejscowe” warunkuje więc, jak Lelewel powie w innym miejscu, „egzystencję całkiem oddzielną" narodu, i chodzi nie tylko chyba o oświeceniową jeszcze teorię klimatu, lecz właśnie o stałość losu, w którym hartują się „stan i natura".

Tak więc mapa może odgrywać rolę księgi przeznaczenia. Ale też z mapy pomocą można ów los nieco kreować, jak zrobił to Lelewel, puszczając w ruch paralelę między Polską a Hiszpanią i ustanawiając równoległość „podźwigania się” obu narodów „w epoce realizacji światowego wyzwolenia”. Dzięki decydującej roli Zachodu w Europie hiszpański „strumień dziejów” miał pełnić funkcję historii wyprzedzającej, podobnie jak potem w paraleli mesjanistycznej Mickiewicza los Polski będzie wyznaczony przez naśladowanie Chrystusa. O tym, że w przeciwieństwie do Mickiewicza nie Francja, ale Hiszpania stała się dla Lelewela prekursorką naszego „podźwigania się”, przesądziło znowu czytanie mapy:

Stanowią one [tj. Hiszpania i Polska] na dwóch krańcach Europy dwie społeczności (14 milionów i 20 milionów) najliczniejsze po ludach Francji i Rosji, skąd wyszedł fatalny cios zadany przez ducha podbojów, który je ostatecznie starł. [L 59]

Oba kraje są zatem na Zachodzie i Wschodzie Europy największymi ofiarami ekspansji silniejszych sąsiadów, stąd też przeobrażenia społeczne (,rewolucja moralna"), w których efekcie mogą się wyzwolić, miałyby ogromną rangę powszechnodziejową.

W emigracyjnej części Historycznej paraleli dwuszpaltowa „histomapa” dziejów hiszpańskich i polskich częściej niż w tekście przedpowstaniowym „zlewa się” i ustępuje wspólnej, wielkiej narracji. Z tekstu wynika bowiem, że „wyprzedzająca” wobec Polski rola Hiszpanii przestała być tak widoczna jak wcześniej, przede wszystkim wszakże jednoszpaltowość zdaje się sygnalizować powszechną i totalną „epokę realizacji światowego wyzwolenia”, w którą aż do Wiosny Ludów wierzył Lelewel.

Historyczna paralela Hiszpanii z Polską, wczesny utwór Joachima Lelewela, dzięki swoim długim dziejom powstawania może być traktowany jako zwierciadło przechadzające się po gościńcu polskiej historii oraz pisarstwa historycznego, również w jego literackiej, Mickiewiczowskiej odmianie. Jako typograficzna metafora historii sygnalizuje - poprzez narrację synchroniczna - kłopot z uzgodnieniem różnorodności historii (m.in. narodowych) z perspektywą powszechnodziejowa, jednocześnie zaś usiłuje go rozwiązać dzięki komparatystycznej grze różnic i podobieństw, zlewania się i rozchodzenia „potoków czasu”. Odzwierciedla też węzłowy punkt przemian narracyjnych - między „historią opisująca” a „historią opowiadająca - moment, w którym świadomość totalności i nie dającego się powstrzymać progresywizmu dziejów dopiero szuka sobie drogi do spójnej i zarazem wielowatkowej opowieści historycznej. Jak się wydaje, prócz fragmentaryzacji pisarstwa historycznego Lelewela ofiarą tego momentu może być także, nie wspomniana tutaj, 
Historia polska Mickiewicza, niedokończona próba dyskursywnego dziejopisarstwa, gdzie narracja wyraźnie nie jest w stanie sprostać mnogości poruszanych wątków. Tymczasem w zastępstwie nieosiagalnej jeszcze wewnętrznej płynności narracji pojawia się u Lelewela graficzny, zewnętrzny obraz „strug czasu” i strug tekstu. Paralelność ma też wymowę ideową, można w niej bowiem widzieć krok ku figuralizacji przekazu historycznego, nadawanie sensu dziejacym się wydarzeniom, ale bez wychodzenia - na pozór - poza racjonalną analizę przejawów życia historycznego, która jest przy tym prowadzona w poszanowaniu autonomii każdego $z$ porównywanych zjawisk (dziejów Polski i Hiszpanii, historii Polski i żywota Chrystusa). Jednak samo ich zestawienie ewokuje już ukazywanie jednej rzeczy przez drugą i uruchamia ową „siłę metaforyzacji”, która dla Haydena White’a, idącego śladem Ericha Auerbacha, stanowi podstawę realizmu figuralnego, nieobcego także stylowi naukowemu ${ }^{34}$.

\section{Abstract \\ DANUTA ZAWADZKA University of Bialystok}

\section{SPACE OF HISTORY, SPACE OF TEXT - MICKIEWICZ'S AND LELEWEL'S PARALLELS}

The article offers a reflection on the changes of early-romantic historical narration in Poland, which the author discusses as based on Joachim Lelewel's and Adam Mickiewicz's texts. The main subject of interest in the paper is Historyczna paralela Hiszpanii z Polska (A Historical Parallel of Spain and Poland) (written in 1820, published in 1831 and continued in the 1830s) and historicism based on parallelism and synchrony. It finds its expression not only in a comparative thinking about history but also in a narrative and graphic "parallelizing" (J. Lelewel). A similarly comparative type of historism is found both in the then scientific and popular historical writing and in literature which, in Mickiewicz's writing rests on a figural presentation of history and Messianism. The success of the parallel at the beginning of $19^{\text {th }} \mathrm{c}$. is by the author linked with a search for a narrative form for a new perception of history conceived as an all-pervasive, multilevel and progressive process, which hardly undergoes a simple diachronic order. 